\title{
TOTAL QUALITY MANAGEMENT FOR CORPORATE SOCIAL RESPONSIBILITY IN SMALL \& MEDIUM ENTERPRISES
}

\author{
Dr. Vijayagiri Bikshapathi \\ Associate Professor and Head, Department of Commerce, SRR Govt. Arts and Science College, Karimnagar, \\ Satavahana University, Karimnagar, Telangana, India
}

Article DOI: https://doi.org/10.36713/epra5997

\begin{abstract}
Total Quality Management (TQM) is the mix of all functions and processes within the organisation to achieve continuous improvement of the quality of goods \& services. TQM concerns about Quality right from the suppliers in the supply chain and focuses on customer satisfaction. Philosophically, TQM System in Japan is integrated, holistic, and wholesome, and doing well.

"Corporate social responsibility is generally understood as being the way through which a company achieves a balance of economic, environmental and social imperatives (Triple-Bottom-Line Approach), while at the same time addressing the expectations of shareholders and stakeholders. The term "corporate social responsibility" even though became popular in the 1960s but has remained a term used indiscriminately. Business ethics is the part of applied ethics that examines ethical principles and moral or ethical problems that can arise in a business environment. ISO 26000 is the recognized international standard for CSR.

This paper suggests a Total Quality Management (TQM) based approach to Corporate social responsibility (CSR). The study examines the characteristics of Corporate social responsibility. The study is based on key quality dimensions viz., reliability, responsiveness, competence, ease of use, security, and product portfolio. The result will help the top management in setting out priorities to achieve sustainable growth using CSR.
\end{abstract}

KEYWORDS: TQM, Quality, Corporate Sustainability, Corporate social responsibility, Business strategy, SMEs.

\section{INTRODUCTION}

Total Quality Management (TQM) is the integration of all functions and processes within the organisation to achieve continuous improvement of the quality of goods \& services. TQM concerns about quality right from the suppliers in the supply chain and focuses on customer satisfaction. Philosophically, TQM System in Japan is integrated, holistic, and wholesome, and doing well. "Corporate social responsibility is generally understood as being the way through which a company achieves a balance of economic, environmental and social imperatives (Triple-Bottom-Line Approach), while at the same time addressing the expectations of shareholders and stakeholders. The term "corporate social responsibility" even though became popular in the 1960s but has remained a term used indiscriminately. Business ethics is the part of applied ethics that examines ethical principles and moral or ethical problems that can arise in a business environment. ISO 26000 is the recognized international standard for CSR. Sustainability i.e. Corporate sustainability essentially refers to the role that companies can play in meeting the agenda of sustainable development and entails a balanced approach to economic progress, social progress, and environmental stewardship.

\section{RESEARCH DESIGN}

The approach adopted for the study constitutes the Objectives, Data collection, etc. The study's main objective is to understand and assess the application of Total Quality Management for the sustainability of small, medium enterprises (SMEs). The study is based on secondary data. The data were collected from the ministry of MSMEs (GOI), State Directorate of Industries, Various websites of Industrial Associations, etc. 
This paper suggests a TQM based approach to achieve Corporate Sustainability. The study examines the characteristics of Corporate Sustainability. The study is based on key quality dimensions viz., reliability, responsiveness, competence, ease of use, security, and product portfolio. The result will help the top management in setting out priorities to achieve sustainable growth.

\section{THE SMALL \& MEDIUM ENTERPRISES IN INDIA}

The micro, small, and medium enterprises (MSME) sector contributes significantly to the manufacturing output, employment, and exports of the country. It is estimated that in terms of value, the sector accounts for about 45 percent of the manufacturing output and 40 percent of the total exports of the country. The sector is estimated to employ about 4.2 Crore persons in over 1.3 Crore units throughout the country. Further, this sector has consistently registered a higher growth rate than the rest of the industrial sector.

Over 6000 products are ranging from traditional to high-tech items, are being manufactured by the MSMEs in India. It is well known that the MSMEs provide the maximum opportunities for both self-employment and jobs after the agriculture sector. Within the MSME sector, the small enterprise sector serves as a greenfield for nurturing entrepreneurial talent and helping the units to grow into the medium and large size. The promotion of MSMEs, therefore, becomes a major area for policy focus, both in developed as well as developing countries.

Table 1: MSMEs Recognition Ceiling Limits in India(As per Act 2006)

\begin{tabular}{|l|l|l|}
\hline \multirow{2}{*}{ Classification } & Manufacturing Enterprises* & Service Enterprises** \\
\cline { 2 - 3 } & (Investment limit up to) & (Investment limit up to) \\
\hline Micro & Rs. 2.5 million / Rs. 25 lakh & Rs. 1 million / Rs. 10 lakh \\
\hline Small & Rs.50 million / Rs. 5 crore & Rs. 20 million / Rs 2 crore \\
\hline Medium & Rs 100 million / Rs 10 crore & Rs. 50 million / Rs 5 crore \\
\hline
\end{tabular}

* Investment limit in Plant \& Machinery $\quad * *$ Investment limit in equipment

Source: http://www.smallindustryindia.com/

As per the data collected for the $4^{\text {th }}$ Census, the size of the registered MSME sector is provisionally estimated to be $15,52,491$. Of the total working enterprises, the proportions of micro, small, and medium enterprises were $95.05 \%, 4.74 \%$, and $0.21 \%$ respectively. This comprises $66.67 \%$ of manufacturing enterprises and $33.33 \%$ of services enterprises. The $8.21 \%(76,654)$ of the manufacturing enterprises were ancillary enterprises. About $45.38 \%(7,04,551)$ of the units were located in rural areas. $28.23 \%(4,31,445)$ enterprises were found to be maintaining accounts. Details in respect of micro, small and medium enterprises are given in the following Table.

TABLE 2: SIZE OF REGISTERED MSME SECTOR (in Numbers)

\begin{tabular}{|l|l|l|l|l|}
\hline Details of Working Enterprises & Micro & Small & Medium & Total \\
\hline \multirow{3}{*}{ Manufacturing } & 974609 & 57666 & 2828 & 1035103 \\
\cline { 2 - 5 } & $(94.16 \%)$ & $(5.57 \%)$ & $(0.27 \%)$ & $(66.67 \%)$ \\
\hline \multirow{2}{*}{ Service } & 501072 & 15915 & 402 & 517389 \\
\cline { 2 - 5 } & $(96.85 \%)$ & $(3.08 \%)$ & $(0.08 \%)$ & $(33.33 \%)$ \\
\hline \multirow{2}{*}{ Total } & 1475681 & 73581 & 3230 & 1552492 \\
\cline { 2 - 5 } & $(95.05 \%)$ & $(4.74 \%)$ & $(0.21 \%)$ & $(100.00 \%)$ \\
\hline
\end{tabular}

Source: Annual Reports 2014-15 www.msme.gov.in.

\section{TOTAL QUALITY MANAGEMENT FRAMEWORK}

Total Quality Management (TQM) is the integration of all functions and processes within an organisation to achieve continuous improvement of the quality of goods \& services. The focus remains on customer satisfaction. It has been widely accepted that TQM is essential for global markets. The concept of TQM strongly believes that a single or couple of Goals achieved by an organization is not the end. A corollary to the TQM concept is that any product, process, or service can be improved. A successful TQM organization is one that consciously seeks \& exploits opportunities for improvements at all levels. The contributory improvement is the watchword of TQM. 
The concept of TQM is based on several ideas. The efforts under the TQM philosophy are to design and build in Quality at every stage and by all means, by focusing on the causes rather than symptoms of poor quality. TQM is a start-to-finish process that integrates inter-related functions at all levels. It is a systems approach that appreciates every interaction between various elements of the organization. Thus, the overall effectiveness of the system is higher than the sum of the individual outputs from the sub-system.

The Quality concepts are shaped at best by World-renowned gurus. Deming's 14 points, Juran's Quality Trio logy, Crossby's Zero Defect, Ishikawa's Quality Control Circles are a few examples.

The Japanese who initiated the quality management system are integrated and philosophically wholesome. This is in contrast to the others who tried individual tools, without knowing their purpose, are found unsuccessful.

\section{CORPORATE SOCIAL RESPONSIBILITY - THE KNOWING:}

According to the UNIDO, "Corporate social responsibility is a management concept whereby companies integrate social and environmental concerns in their business operations and interactions with their stakeholders. CSR is generally understood as being the way through which a company achieves a balance of economic, environmental, and social imperatives (Triple-Bottom-Line Approach), while at the same time addressing the expectations of shareholders and stakeholders. In this sense, it is important to distinguish between CSR, which can be a strategic business management concept, and charity, sponsorships, or philanthropy. Even though the latter can also make a valuable contribution to poverty reduction, will directly enhance the reputation of a company and strengthen its brand, the concept of CSR goes beyond that."

The CSR approach is holistic and integrated with the core business strategy for addressing the social and environmental impacts of businesses. CSR needs to address the well-being of all stakeholders and not just the company's shareholders. Philanthropic activities are only a part of CSR, which otherwise constitutes a much larger set of activities entailing strategic business benefits.

CSR in India has traditionally been seen as a philanthropic activity. And in keeping with the Indian tradition, it was an activity that was performed but not deliberated. As a result, there is limited documentation of specific activities related to this concept. However, what was evident that much of this had a national character encapsulated within it, whether it was endowing institutions to actively participating in India's freedom movement, and embedded in the idea of trusteeship.

As some observers have pointed out, the practice of CSR in India remains within the philanthropic space but has moved from the institutional building (educational, research, and cultural) to community development through various projects. Also, with global influences and with communities becoming more active and demanding, there appears to be a discernible trend, that while CSR remains largely restricted to community development, it is getting more strategic (that is, getting linked with business) than philanthropic, and a large number of companies are reporting the activities they are undertaking in this space in their official websites, annual reports, sustainability reports and even publishing CSR reports.

The Companies Act, 2013 has introduced the idea of CSR to the forefront and through its disclose-orexplain mandate, is promoting greater transparency and disclosure. Schedule VII of the Act, which lists out the CSR activities, suggests communities be the focal point. On the other hand, by discussing a company's relationship with its stakeholders and integrating CSR into its core operations, the draft rules suggest that CSR needs to go beyond communities and the concept of philanthropy. It will be interesting to observe how this will translate into action at the ground level, and how the understanding of CSR is set to change.

\section{PROSPECTIVE BUSINESS BENEFITS OF CSR}

Review of extensive literature list out non-financial measures of success (e.g., Deming's Fourteen Points, balanced scorecards). While CSR benefits are hard to quantify, Orlitzky, Schmidt, and Rynes found a correlation between social/environmental performance and financial performance.

\section{Triple Bottom Line}

"People, planet and profit", also known as the triple bottom line form one way to evaluate CSR. "People" refers to fair labour practices, the community, and the region where the business operates. "Planet" refers to sustainable environmental practices. Profit is the economic value created by the organization after deducting the cost of all inputs, including the cost of the capital (unlike accounting definitions of profit).

This measure was claimed to help some companies be more conscious of their social and moral responsibilities. However, critics claim that it is selective and substitutes a company's perspective for that of the community. Another criticism is about the absence of a standard auditing procedure.

\section{Human Resources}

A CSR program can be an aid to recruitment and retention, particularly within the competitive graduate student market. Potential recruits often consider a firm's CSR policy. CSR can also help improve the perception 
of a company among its staff, particularly when staff can become involved through payroll giving, fundraising activities, or community volunteering. CSR has been credited with encouraging customer orientation among customer-facing employees.

\section{Risk Management}

Managing risk is an important executive responsibility. Reputations that take decades to build up can be ruined in hours through corruption scandals or environmental accidents. These draw unwanted attention from regulators, courts, governments, and media. CSR can limit these risks.

\section{Brand Differentiation}

CSR can help build customer loyalty based on distinctive ethical values. Some companies use their commitment to CSR as their primary positioning tool, e.g., The Co-operative Group, The Body Shop, and American Apparel.

Some companies use CSR methodologies as a strategic tactic to gain public support for their presence in global markets, helping them sustain a competitive advantage by using their social contributions as another form of advertising.

\section{Reduced Scrutiny}

Corporations are keen to avoid interference in their business through taxation and/or regulations. A CSR program can persuade governments and the public that a company takes health and safety, diversity, and the environment seriously, reducing the likelihood that company practices will be closely monitored.

\section{Supplier Relations}

Appropriate CSR programs can increase the attractiveness of supplier firms to potential customer corporations. E.g., a fashion merchandiser may find value in an overseas manufacturer that uses CSR to establish a positive image - and to reduce the risks of bad publicity from uncovered misbehavior.

\section{CORPORATE SUSTAINABILITY - ENRICHMENT OF CSR CONCEPT}

Sustainability (corporate sustainability) is derived from the concept of sustainable development which is defined by the Brundtland Commission as "development that meets the needs of the present without compromising the ability of future generations to meet their own needs". Corporate sustainability essentially refers to the role that companies can play in meeting the agenda of sustainable development and entails a balanced approach to economic progress, social progress, and environmental stewardship.

CSR in India tends to focus on what is done with profits after they are made. On the other hand, sustainability is about factoring the social and environmental impacts of conducting business, that is, how profits are made. Hence, much of the Indian practice of CSR is an important component of sustainability or responsible business, which is a larger idea, a fact that is evident from various sustainability frameworks. An interesting case in point is the NVGs for social, environmental, and economic responsibilities of business issued by the Ministry of Corporate Affairs in June 2011. Principle eight relating to inclusive development encompasses most of the aspects covered by the CSR clause of the Companies Act, 2013. However, the remaining eight principles relate to other aspects of the business. The UN Global Compact, a widely used sustainability framework has 10 principles covering social, environmental, human rights, and governance issues, and what is described as CSR is implicit rather than explicit in these principles.

\section{CORPORATE SOCIAL RESPONSIBILITY AND SMALL AND MEDIUM ENTERPRISES}

The business activities of SMEs are performed near to the locals. This enables them to be aware of community needs, manage expectations, and develop CSR programmes appropriately. Now that the CSR clause in the Companies Act, 2013 covers companies that have a net profit of FIVE crore rupees and above, many small and medium enterprises (SMEs) will qualify but not the micro- enterprises. The CSR activities of these SMEs are driven by the personal interests of owners/promoters who hold a significant financial stake in the business. They tend to be in clusters and engaged in similar business activities. While the quantum of revenue available for CSR with individual SMEs is usually to be small, all eligible companies in a specific geographical cluster, who single-handed as well as collectively impact the same community, can pool their resources to create a sizeable CSR fund. This collaboration can also be used by other companies to maximize the impact of their CSR initiatives while reducing the operational costs for fund management. CSR is for all companies. SMEs in India have participated in CSR activities but these efforts have not been optimally delivered. One possible reason can be the fact that CSR activities depend on the profits of an SME and any fluctuations in profits can adversely affect their capability to continue their contribution to CSR. Another reason can be the limited human resources available to SMEs which may also result in the lack of a professional approach. 
SMEs tend to focus on short-term activities that involve lesser operational costs. A survey conducted by UNIDO in 2008 on five SME clusters in India, found that $31 \%$ to $79 \%$ of the SMEs in these clusters, preferred charity donations rather than long-term programmes for local communities.

With the introduction of the new Companies Act, 2013, the SME's approach to CSR has to be modified while keeping operational costs low. One viable alternative is to pool resources with other SMEs in the cluster and create joint CSR programmes managed by a single entity. This collaboration can be formed within the units in a cluster as they interact with the same communities and have already established associations that cater to the business needs of the units. Collaboration has the following advantages:

Reduces operational cost: Individual CSR efforts by a company consist of establishing a CSR department, assessing the needs of local communities, undertaking programmes directly or through an NGO, and conducting regular impact assessment studies. A common organisation catering to several companies will carry out these activities collectively and thus reduce the operational cost of management.

Undertake long-term projects: A major hindrance in developing long-term projects is the uncertainty in the CSR budget. This is dependent on the financial performance of the company. A fluctuating performance implies that the CSR budget allocations can be unreliable and can jeopardise a programme initiated earlier.

Communities provide the license to operate: Apart from internal drivers such as values and ethos, some of the key stakeholders that influence corporate behaviour include governments (through laws and regulations), investors, and customers. In India, a fourth and increasingly important stakeholder in the community, and many companies have started realising that the 'license to operate' is no longer given by governments alone, but by communities that are impacted by a company's business operations. Thus, a robust CSR programme that meets the aspirations of these communities not only provides them with the license to operate but also to maintain the license, thereby precluding the 'trust deficit'.

Attracting and retaining employees: Several human resource studies have linked a company's ability to attract, retain, and motivate employees with their CSR commitments. Interventions that encourage and enable employees to participate are shown to increase employee morale and a sense of belonging to the company.

Communities as suppliers: Certain innovative CSR initiatives are emerging, wherein companies have invested in enhancing community livelihood by incorporating them into their supply chain. This has benefitted communities and increased their income levels while providing these companies with an additional and secure supply chain.

Enhancing corporate reputation: The traditional benefit of generating goodwill, creating a positive image, and branding benefits continue to exist for companies that operate effective CSR programmes. This allows companies to position themselves as responsible corporate citizens

\section{CONCLUSIONS}

The extension to TQM will build on the existing academic and organisational reputation. TQM will meet the demands of the large-scale market and organisational change. As the business environment gets increasingly complex and stakeholders become vocal about their expectations, good CSR practices can only bring in greater benefits in the long run.

\section{REFERENCES}

1. 1.http://www.pwc.in/assets/pdfs/publications/2013/handbook-on-corporate-social-responsibility-in-India.pdf

2. 2.http://articles.economictimes.indiatimes.com/2013-06-09/news/39834857_1_smes-workforce-small-andmedium-enterprises

3. http://www.business-standard.com/article/sme/smes-to-get-professional-help-on-corporate-socialresponsibility-108060501090_1.html

4. http://bsieducation.org/Education/downloads/ijqs/paper2.pdf

5. http://www.ugb.ro/etc/etc2011no1/CSR-9-full.pdf

6. http://www.culturaldiplomacy.org/academy/content/pdf/ biec/The_Impact_of_Corporate_Social_Responsibility_on_Business_Performance_-_Malte_Kaufmann.pdf

7. https://dspace.uevora.pt/rdpc/bitstream/10174/3594/1/Quality\%20and \%20Social\%20 Responsibility.pdf

8. Juran, J.M., 1986, The quality trilogy, Quality Progress, 9(8), 19-24.

9. Karuppusami, G., Gandhinathan. R. 2006, Pareto analysis of critical success factors of total quality management: A literature review and analysis", TQM Magazine, Vol.18 No.4 pp. 372-385.

10. Rao, S.S., Ragu-Nathan, T.S. And Solis, L.E., 1997, Does ISO 9000 have an effect on quality management practices? An international empirical study, Total Quality Management, 8(6), 335-346.

11. Bhattacharya, CB; Sen, Sankar; Korschun, Daniel (2011). Leveraging Corporate Social Responsibility: The Stakeholder Route to Business and Social Value. Cambridge: UK: Cambridge University Press. 
EPRA International Journal of Environmental Economics, Commerce and Educational Management Journal DOI: 10.36713/epra0414 |ISI I.F Value: 0.815|SJIF Impact Factor (2020): 7.572

12. SME India, "SSI sector in various states in India" http://www.smeindia.com/ssi.variousstates.asp., 2001.

13. Tewari, V.K., J.Phillip, A.N.Pandey, "Small scale industries. Success and failures." Concept Publishing Company, New Delhi, 1990.

14. Bikshapathi, Vijayagiri (2014), "Total Quality Management for Small \& Medium Enterprises in India" Published by Scholars' Press with ISBN Number 978-3-639-66192-7 pages 324. 